\title{
The innovative research of university ideological and political education in the view of marxism-leninism
}

\author{
Yao Bingyang \\ Northwestern Polytechnical University, CHINA \\ 13081040660@163.com
}

Key words: Colleges and universities; Thought politics education; Innovative; marxism-leninism

\begin{abstract}
Both of our country's socialist construction and the ideological and political education in colleges and universities are based on marxism-leninism as the basic guiding ideology on the basis of, in terms of the present stage, as the basis of our country enterprise education career, with the development of The Times, changes to keep pace with The Times is the inevitable trend of the development of ideological and political education in colleges and universities is to students through one of the important content, how is environment based on the perspective of marxism ideological and political education in colleges and universities become one of the important content of teaching innovation. This paper takes this as the starting point and delve deeply into the innovative research of university thought politics education in the field of marxism-leninism.
\end{abstract}

Quote: Ideological and political education has always been an important part of the education system in colleges and universities, it can help students develop and set up the correct through conscious, rational thoughts on events and put forward their own views, right for college students, the ideological and political education is an important course along with their lives. And the rapid development of The Times, for the cause of education teaching traditional teaching forms, teaching methods, teaching concept and teaching contents are generating varying degrees of impact, how to on this basis, further to the development of the education teaching activities, and in male body under the central idea of the content of innovation become the key.

\section{Correct understanding of ideological and political education.}

Ideological and political education is a rich proposition, the ideological and political education in colleges and universities is based on marxism-leninism, under the central idea of the right through to set up and guidance for students, help students to understand the current events, and learn to use the right attitude and the method to express their views and ideas, but in the actual teaching process, it always exists some deep-rooted problems need to be solved.

\subsection{The importance of political education.}

College students is one of the distinctive group of students, especially college students under the new era, grew in the rise and popularization of the Internet s, they earlier begin to contact the Internet, more and more comprehensive understanding of knowledge interpretation of information channels, that itself is very good, their thinking and therefore becomes active, but at the same time, the Internet information of different mixed with a large number of information, and a lot of misleading information, for the students' thinking, ideas, or even through will adversely affect, the vast majority of adult college students, and has formed a relatively mature through, They are the important driving force for social innovation and development, so it is extremely important to carry out ideological and political education at this critical time. ${ }^{[1]}$

\subsection{At present, the main problems are analyzed.}

In the process of practical teaching, many students even teachers generally do not attach importance to the course, it is thought that the nature of the curriculum theory, and from the real life, there is no relationship, their learning interest and enthusiasm to drop, there is blind a perfunctory phenomenon, 
this was partly due to the teacher's teaching methods are single, some teachers just put forward from the textbook knowledge, blackboard writing teaching, in order to test for the final purpose of teaching, caused the teaching in the teaching environment and atmosphere gradually theoretical, and with the minds of students ${ }^{[2]}$; On the other hand is due to the information age for students thinking, many students are misleading information, think you already know to master the content, and not willing to the content of the teaching of learning.

In addition, for students in the teaching of misunderstanding itself also has affected the further innovation and extension of teaching activities, many students think marxism-leninism is "old", does not have the characteristics of the new era, is not suitable for the development of the new era, the ideological and political education is also so"old" ${ }^{[3]}$,It doesn't fit with the current trend of young people. Learning becomes a burden, only for credit. The emergence of this kind of thinking and not surprisingly, in college students, occupied most of the proportion of this kind of thinking, this has something to do with student own growth environment, also associated with teaching does not reach the designated position, either way, marxism-leninism is unshakable position in China, the development of ideological and political education teaching activities is also very necessary, how to adapt to the students' teaching activities, and on the basis of innovation is key.

\section{Explore and expound the way of innovative teaching.}

As for the innovative teaching of education in college ideological and political science, the central idea and the main idea of teaching should not be abandoned.Under the guidance of marxism-leninism, it helps students to set up the right three views and to convey the right talents to the society. Secondly, we should combine the characteristics of the new age background to carry out teaching.

\subsection{The application of new media technology.}

The application of new media technology in this paper is not the new internet-based technology.The use of the equipment, but based on the development of The Times, big data brings the application of network new media. Compared with traditional media, network new media has unique advantages that traditional media cannot match ${ }^{[4]}$, First is on the spread of information, transmission speed, range is very wide, "Internet" has become the conventional means of media reports for the event, by using this feature, let the public in the shortest possible time, attention to this matter and generate discussion; In addition the speed of information update quickly, at any time within the same day in the update hot news events, but it also brings the advantages of less than, is mentioned in this paper, information on the quality problem, information spread through a large number of good and bad are intermingled, easily for students ideological political consciousness is poorer, imperfect network supervision means also contributed to this phenomenon, therefore, combined with the advantages and disadvantages of new media, for the use of new media is very important.

The use of new media, the first should occupy a certain network platform, through the identity of the colleges and universities in a relatively well-known platform registered official account, such as number, micro letter public account $\mathrm{V}$, etc., and then through the analysis of some hot issues for the comments, to guide students to realize the social situation, understand the social development direction, regard the question into the guide students through the marxist-leninist ideology, realizes the student to the understanding of the ideological and political education and interpretation, and fully in this way, let the students recognize the marxism-leninism with the era development and continuous development of innovation, is not constrained by a thought of theories, Marxism-leninism is an outstanding contribution to China's development and its tenacious vitality ${ }^{[5]}$.

\subsection{Further study and promotion of marxism-leninism.}

While the new media is fully utilized, the teaching of ideological and political education should also be carried out.Different forms of teaching, enriching the teaching and improving the efficiency of communication, create a high-quality cultural learning space on the Internet for college students.

This requires the related education teaching workers to be able to keep up with the trend of The 
Times, and a wide range of study and application of new media, in the network information platform, establish the base of ideological and political education culture, and promotion and development, and continuously promote the education teaching new changes at the same time, the marxist thoughts of further study and promotion.

\subsection{The innovative combination of theory and practice.}

College students are able to access a wider range of information carriers, and can also browse through various kinds of information.Information, the corresponding can produce all kinds of thinking, and some of these thinking is just a flash in the pan, a flash, while others take root in students mind, cause they think, others like is difficult to solve the problem, has become the burden on students thought this was affecting students' ideological and political development, set up correct through one of the important factors.

So for ideological and political education of innovative research, should also be combined with practice, realize the innovative combination of theory and practice, based on the actual teaching activities, is the problem for the student's thought to answer the basic work, to help students on the side to accept political education, improve the quality of ideological and political teaching, realize the education goal ${ }^{[6]}$. This way of solution, can be the reality of the interaction between teachers and students, the network interaction, also can be the media platform in the hospital and the interaction between the groups of students, different forms of interaction can produce different effect, thus bring different resonance for students, to the improvement of education teaching efficiency and quality, also to the effect of the wasted effort. In combination with the new era, students have a deeper understanding of marxism-leninism and are more willing to explore and study in depth.

\subsection{Innovation in teaching form.}

The innovation of teaching form is based on the correct orientation of ideological and political orientation.On the basis of guidance, the innovation of teaching form. The innovation of education form is mainly analyzed from two aspects, on the one hand, it is based on the innovation of classroom teaching form. Ideological and political education at the same time, same with other teaching teachers generally like or good at using the courseware PPT, for teaching material, examination tests, understanding the way student achievement, to complete for the teaching of ideological and political education, the teaching form is in strong behavior students ideological and political idea, students easy to produce resistance in studying for a long time. And innovation needs to be reflected in all aspects, such as the production of courseware, to be closer to the students' style; Teaching explanation is more derivative and more attractive; In the teaching activities, interspersed with some interesting links, such as q\&a, dialogue and imitation, to increase the interest of the class. The innovation of the whole teaching detail is the biggest innovation of the teaching form, the students find different from the details, arouse curiosity, and then improve the interest in learning and improve the quality of teaching.

On the other hand, it is based on the innovation of after-school teaching form and teaching evaluation. After class teaching form is mainly refers to the mentioned above, to guide students to take advantage of new media, another way to achieve teaching innovation, while the teaching evaluation innovation refers to the evaluation of teaching content, forms of innovation to improve the durability of students for learning enthusiasm. The traditional teaching evaluation standard is single use test scores to realize the teaching evaluation, its drawback is that ignores the individual difference of students, especially college students, their interests and hobbies, is good at with the content of the advantage is not the same, only through the result to assess student itself is not complete. So teachers' ideological and political education teaching evaluation, should be based on students' life, learning attitude, learning all aspects such as comprehensive evaluation, the best in both see student, also pointed out the shortcomings of students, help students to achieve correct them. In the form of evaluation, the evaluation of students from a single teacher can be transformed into teachers' evaluation of students and students for teachers and students. College students already have a certain mature ideas, this evaluation form on the one hand, can help teachers to recognize my 
own shortcomings, on the other hand, can effectively improve students' ideological and political education for the application of the implementation process of the teaching effect, it is not only the innovation of ideological and political education in colleges and universities, is also the innovation of teaching methods for the education, is also based on the development of the era background, facing the innovation education teaching career path.

\section{Conclusion}

For our country, marxism-leninism is to guide the country to build up, grow and win in many difficulties, and move forward.Important content in the thought of development, our country still in the primary stage of socialism, marxist thought of learning is very important, and the changing of times development, and learning can't stop the footsteps, the pace of innovation, can't stop how on this foundation, has always been unswervingly carry out to marxism-leninism learning, and on the basis of the study on the cause of education innovation is the present major problems of ideological and political education. This article through to marxism-leninism explore the innovative ideological and political education from the perspective, from teaching concept, teaching method, teaching form and is separated from the combination of new media, hope that the general education workers continue to delve into, as the ideological and political education innovation, to provide more opinions and Suggestions, in order to promote the socialist modernization construction and development, render contribution.

\section{References:}

[1] Sun Xiaohui.The innovative discussion of university ideological and political education in the view of marxism-leninism.[J].New Campus, 2014(10):65-66.

[2] Zhang Xiaoxun. The ideological and political education of the university under the popular view of marxism.[D].Journal of Zhejiang Normal University, 2014.

[3] GuanXueQing.Research on the education path of university ideology and politics under the popular view of marxism.[D].Journal of Chongqing Jiaotong University, 2013.

[4] XiJing. The education method of university thought politics under the popular view of marxism.[J].Course Education Research, 2017(14):115-117.

[5] Wang Jingling.Research on the education mode of university ideology and politics under the development of marxism in contemporary China.[J].Management \& Technology of SME, 2015(08):44-44.

[6] GuanCuiLing. The ideological and political education practice innovation in the view of marxism humanism.[J].Ability and Wisdom, 2015(06):132-133. 